Systematic Review

\title{
An Evaluation of the Potential of Essential Oils against SARS-CoV-2 from In Silico Studies through the Systematic Review Using a Chemometric Approach
}

\author{
Luiz Torres Neto ${ }^{1,2,3,4}$ (), Maria Lúcia Guerra Monteiro ${ }^{1,2,3,4,5}$ (D) Diego Galvan ${ }^{1,2,4}$ (1) \\ and Carlos Adam Conte-Junior 1,2,3,4,5,6,*iD \\ 1 COVID-19 Research Group, Center for Food Analysis (NAL), Technological Development Support \\ Laboratory (LADETEC), Cidade Universitária, Rio de Janeiro 21941-598, Brazil; \\ luiztorresneto@ufrj.br (L.T.N.); marialuciaguerra@yahoo.com.br (M.L.G.M.); diegogalvann@gmail.com (D.G.) \\ 2 Laboratory of Advanced Analysis in Biochemistry and Molecular Biology (LAABBM), Department of \\ Biochemistry, Federal University of Rio de Janeiro (UFRJ), Cidade Universitária, \\ Rio de Janeiro 21941-909, Brazil \\ 3 Graduate Program in Food Science (PPGCAL), Institute of Chemistry (IQ), Federal University of Rio de \\ Janeiro (UFRJ), Cidade Universitária, Rio de Janeiro 21941-909, Brazil \\ 4 Institute of Chemistry, Federal University of Rio de Janeiro, Avenida Athos da Silveira Ramos, n. 149, Bloco A, \\ $5^{\circ}$ Andar, Rio de Janeiro 21941-909, Brazil \\ 5 Graduate Program in Veterinary Hygiene (PPGHV), Faculty of Veterinary Medicine, Fluminense Federal \\ University (UFF), Vital Brazil Filho, Niterói 24220-000, Brazil \\ 6 Graduate Program in Sanitary Surveillance (PPGVS), National Institute of Health Quality Control (INCQS), \\ Oswaldo Cruz Foundation (FIOCRUZ), Rio de Janeiro 21040-900, Brazil \\ check for \\ updates \\ * Correspondence: conte@iq.ufrj.br; Tel.: +55-21-3938-7825
}

Citation: Torres Neto, L.; Monteiro, M.L.G.; Galvan, D.; Conte-Junior, C.A. An Evaluation of the Potential of Essential Oils against SARS-CoV-2 from In Silico Studies through the Systematic Review Using a Chemometric Approach. Pharmaceuticals 2021, 14, 1138. https://doi.org/10.3390/ph14111138

Academic Editor: Daniela De Vita

Received: 20 October 2021

Accepted: 4 November 2021

Published: 10 November 2021

Publisher's Note: MDPI stays neutral with regard to jurisdictional claims in published maps and institutional affiliations.

Copyright: (c) 2021 by the authors. Licensee MDPI, Basel, Switzerland. This article is an open access article distributed under the terms and conditions of the Creative Commons Attribution (CC BY) license (https:/ / creativecommons.org/licenses/by/ $4.0 /)$.
Abstract: Essential oils (EOs) and their compounds have attracted particular attention for their reported beneficial properties, especially their antiviral potential. However, data regarding their anti-SARS-CoV-2 potential are scarce in the literature. Thus, this study aimed to identify the most promising EO compounds against SARS-CoV-2 based on their physicochemical, pharmacokinetic, and toxicity properties. A systematic literature search retrieved 1669 articles; 40 met the eligibility criteria, and 35 were eligible for analysis. These studies resulted in $465 \mathrm{EO}$ compounds evaluated against 11 human and/or SARS-CoV-2 target proteins. Ninety-four EO compounds and seven reference drugs were clustered by the highest predicted binding affinity. Furthermore, 41 EO compounds showed suitable drug-likeness and bioactivity score indices ( $\geq 0.67)$. Among these EO compounds, 15 were considered the most promising against SARS-CoV-2 with the ADME/T index ranging from 0.86 to 0.81 . Some plant species were identified as EO potential sources with anti-SARS-CoV-2 activity, such as Melissa officinalis Arcang, Zataria multiflora Boiss, Eugenia brasiliensis Cambess, Zingiber zerumbet Triboun \& K.Larsen, Cedrus libani A.Rich, and Vetiveria zizanoides Nash. Our work can help fill the gap in the literature and guide further in vitro and in vivo studies, intending to optimize the finding of effective EOs against COVID-19.

Keywords: COVID-19; plant species; volatile compound; antiviral activity; hierarchical cluster analysis (HCA)

\section{Introduction}

Essential oils (EOs) are volatile liquids extracted from whole or parts of aromatic plants such as bark, fruits, flowers, and leaves [1]. These compounds have a broad biological spectrum with antimicrobial, antifungal, insecticide, anti-inflammatory, antioxidant, anticarcinogenic, and antiviral actions [2]. Accordingly, interest in EOs has been increasing in different fields, such as food, pharmaceutical, cosmetic, and medical applications [2,3]. In this way, the biological potential of these compounds can be valuable for combating the COVID-19 pandemic. 
The disease caused by SARS-CoV-2 (COVID-19) is still causing infection and mortality worldwide. More than 245 million people have been infected worldwide, with almost five million deaths by mid-October 2021 [4]. The large influx of patients challenged the health systems of several countries. Thus, numerous public health measures are still needed to contain virus transmission [5], mainly by new mutations and expected variants [6], despite the large vaccination campaigns already started in several countries [7].

The symptoms of SARS-CoV-2 are similar to severe acute respiratory syndrome coronavirus (SARS-CoV) and Middle Eastern respiratory syndrome coronavirus (MERS$\mathrm{CoV})$, which have an incubation period of two weeks for express signs such as fever, cough, dyspnea, and lung damage [8]. The infection process occurs through a specific receptor called angiotensin-converting enzyme-2 (ACE2), which allows the virus entry into the host cell through the active receptor-binding domain (RBD) in the spike protein (Spro) found on the virus surface $[9,10]$. Recent studies show that blocking ACE2 and the Spro is one possible way of preventing SARS-CoV-2 from entering the target cell. Thus, compounds with the potential to inhibit one of these proteins would be critical for identifying new anti-SARS-CoV-2 compounds [9,11].

The antiviral potential of EOs is attributed to their composition of mono- and sesquiterpenes hydrocarbons. These compounds are promising in prospecting studies of antiviral molecules [12]. Furthermore, the antiviral action of some EOs is already known against viruses such as human herpes virus (HSV), influenza A virus (H1N1), avian influenza A virus (H5N1), Zika virus, and human immunodeficiency virus (HIV), among others [13]. In association with the increasing demand for natural and safe products, these facts make EOs a potential alternative to aid in combating COVID-19.

Review studies have assumed that EOs have antiviral potential against SARS-CoV-2 due to their known action against several other viruses and for managing symptoms in patients with COVID-19 [14-17]. Despite that, there is little data gathered regarding the active potential of EOs against the SARS-CoV-2 virus. In this context, the present study aimed to identify the most promising EO compounds and potential EO sources against COVID-19 based on their affinity by target proteins, drug-likeness, bioactivity score, and $\mathrm{ADME} / \mathrm{T}$ through a systematic review and chemometric analysis.

\section{Material and Methods}

In this study, we systematically retrieved data available in online databases on studies relating to the antiviral potential of compounds from EOs against SARS-CoV-2 following the Preferred Reporting Items for Systematic Review and Meta-Analyses (PRISMA; http: / / www.prisma-statement.org/PRISMAStatement/; accessed on 15 August 2021) guidelines (see Supplementary File 1 and Figure 1) [18], and StArt software [19] was used.

\subsection{Focus Questions}

The focus issue was determined according to the population, intervention, comparison, and outcome (PICO) method. The research questions were based on the following form:

(P) Do EO compounds have potential action against SARS-CoV-2?

(I) Which EO compounds have been studied for action against SARS-CoV-2?

(C) What are the possible mechanisms of action and the most promising EO compounds against SARS-CoV-2?

(O) What are the botanical genera with the most expressive action against SARS-CoV-2?

\subsection{Information Source}

An exploratory analysis without a specific period was previously performed on Google Scholar using strings that summarize the issues raised: (COVID-19 OR Coronavirus OR SARS-CoV-2 OR "COVID-19 Pandemic") AND "Essential oil" AND (Viral OR Antiviral OR "Viral action" OR "Antiviral activity" OR "Antiviral agent"). This step was performed to identify the main words and their synonyms used in the title, abstract, and keywords of 
articles related to the subject of this study for subsequent building of the search components (SC).

\section{IDENTIFICATION}

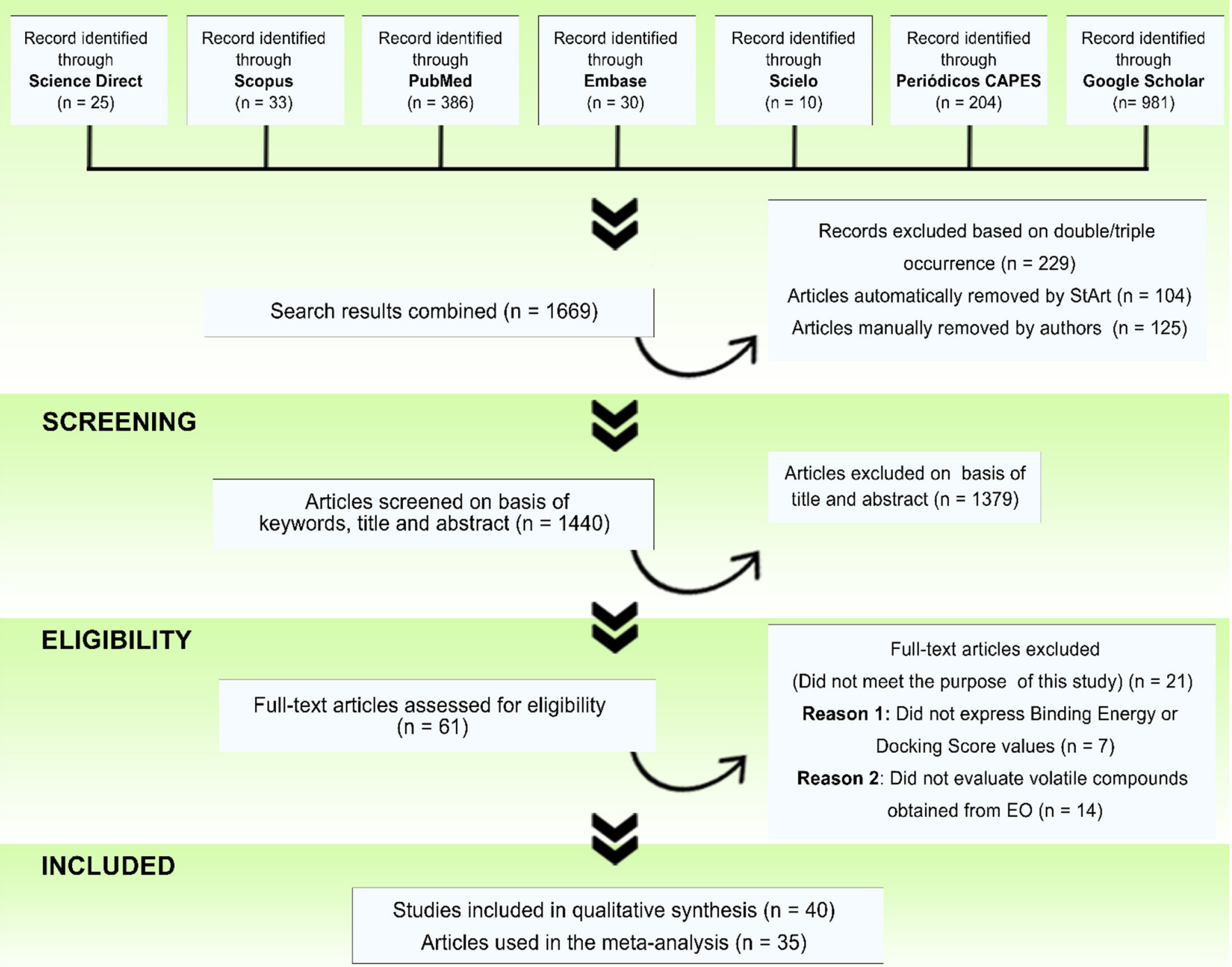

Figure 1. Flow diagram displaying the results of the systematic literature search about the antiviral potential of compounds from essential oils (EOs) against SARS-CoV-2 between 2019 and 2021 through Preferred Reporting Items for Systematic Review and Meta-Analyses (PRISMA) and StArt software [18,19].

The search was based on online databases, using PubMed, Scopus, Embase, Science Direct, Google Scholar, SciELO, and the Higher-Level Personnel Improvement Coordination Gateway (Periódicos CAPES). Periódicos CAPES is a vast virtual library that allows simultaneous access to PubMed, Web of Science, Scopus, Springer Link, Wiley Online Library, Taylor \& Francis Online, and Embase. The entire search process in the databases was carried out between 4 and 6 May 2021, identifying studies published between 2019 and 2021, according to the following search strings:

Search component 1 (SC1): SARS-CoV-2 OR COVID-19 OR 2019-nCoV OR Coronavirus Search component 2 (SC2): "Essential Oil" OR "Volatile Oil"

Search component 3 (SC3): Antiviral OR Virucide

After retrieving the search component results, the Boolean operator "AND" combined $\mathrm{SC} 1, \mathrm{SC} 2$, and SC3. 


\subsection{Inclusion/Exclusion Criteria}

All screening processes were performed by L.T.N. and M.L.G.M. The replicated studies were automatically eliminated by the StArt software from each database, and a manual exclusion was also performed. Then, the articles were screened based on the title, abstracts, and keywords according to the eligibility criteria. The inclusion criteria used in this study were:

(i). Articles published in the English language;

(ii). Peer-reviewed original articles and preprints;

(iii). Studies evaluating the activity of compounds from EOs concerning their anti-SARSCoV-2 action in silico and/or in vitro.

The exclusion criteria used were:

(i). Abstracts, books, conference articles, editorials, letters, reviews, meta-analyses, presentations, reviews, and doctoral theses;

(ii). Articles evaluating the antiviral action of compounds from EOs on other viruses;

(iii). Articles that evaluated the antiviral action of other compounds against SARS-CoV-2;

(iv). Studies evaluating the effect of EO compounds against SARS-CoV-2 but without considering the target parameters of this study.

Articles that generated doubts regarding the eligibility criteria were considered for a full reading.

\subsection{Evaluation of Articles, Data Extraction, and Analyses}

After reading the articles in full, 40 articles were eligible for the present study (Figure 1), of which 92.5\% $(n=37)$ were molecular docking (MD) studies of EO compounds against target proteins that participate in the process of infection and viral replication of SARS-CoV-2 in the human cell [3,9,20-54]. Only $7.5 \%(n=3)$ were in vitro studies [55-57]. Due to the low number of in vitro studies, they were not included in the statistical analysis. However, they were systematically demonstrated to reinforce our findings in a complementary way. Data extracted from all eligible in silico studies were sent to an MS Excel spreadsheet, following the criteria: name of the first author followed by "et al"., year of publication, EO source, evaluated EO compound (including reference drugs), human and /or SARS-CoV-2 protein targets, binding energy (BE), and docking score (DS) values. When applicable, BE and DS values were converted to $\mathrm{Kcal} / \mathrm{mol}$.

The data extracted from the MD studies generated a set of 1271 data with a total of $465 \mathrm{EO}$ compounds, 13 reference drugs, and 11 target proteins. The mean was calculated for the BE and DS values of the same compounds evaluated against the same target proteins, and it was considered in our study when the coefficient of variation $(\mathrm{CV})$ was less than 8 . Otherwise, the average was considered an outlier. Furthermore, some BE and DS values of different compounds in the same protein were considered outliers within our data set $[26,38]$.

After that, the BE and DS values were submitted to a hierarchical cluster analysis (HCA) together with a heat map graph (Section 2.6). This analysis aimed to aggregate the compounds with more significant similarities into clusters, identifying those with spontaneous binding potential (lower BE and DS values) in each target protein [58,59]. In other words, the most promising EO compounds against SARS-CoV-2 based on BE and DS values were identified for further characterization regarding their physicochemical, pharmacokinetic, and toxicity properties.

\subsubsection{Drug-Likeness Prediction}

Lipinski's rule of five (RO5) is a significant parameter for describing the molecular properties of compounds for estimating important pharmacokinetic parameters. Ghose's rule is a filter designed to improve drug similarity predictions [60], and Muegge's rule is based on the presence of structural fragments typically found in drugs [61]. All EO compounds and reference drugs were tested for Lipinski's rule with the web-based tool 
Molinspiration (https:/ / www.molinspiration.com/; accessed on 15 August 2021) [62], and Ghose's and Muegge's rules through the SwissADME server (http:/ / www.swissadme.ch/; accessed on 15 August 2021) [63].

The promising compounds are those with no violations or at most one violation of these rules. Therefore, using Lipinski's, Ghose's, and Muegge's rules violation data, a drug-likeness index (DLI) was created by assigning values of 1 (violation $=0$ ) and 0 (violation $\geq 1)$ through the formula: DLI $=($ Lipinski + Ghose + Muegge $) /\left(n_{\text {total rules }}\right)$. The DLI indices were subjected to HCA with a heat map graph, in which promising EO compounds were those clustered by a DLI equal to or greater than 0.67 .

\subsubsection{Bioactivity Score Prediction}

The bioactivity score of each EO compound and the reference drugs was predicted using the Molinspiration tool. This allows for the identification of the bioactivity of drug candidates in some human receptors [64], such as binding to the G protein-coupled receptor (GPCR) ligand and nuclear receptor ligand, ion channel modulation, kinase inhibition, protease inhibition, and enzyme activity inhibition [62]. Using the data generated by the tool, scores were assigned to the activity of each compound: 1 (inactive $>-0.50$ ), 2 (moderately active from -0.50 to 0.00 ), and 3 (active $>0.00$ ), according to previously defined criteria [65]. The scores were used to calculate the bioactivity score index (BSI): BSI = (GPCRs + nuclear receptors + ion channels + kinases + proteases + enzymes $) /\left(n_{\text {sum of scores }}\right)$. The BSI indices were subjected to HCA with a heat map graph, considering values equal to or greater than 0.67 as promising.

\subsubsection{ADME/T}

The compounds with the highest DLI and BSI scores were evaluated for pharmacokinetic and toxicity properties (ADME/T). First, 22 parameters of the absorption, distribution, metabolism, excretion, and toxicity of the compounds were evaluated by the ADMETlab server (http:/ / admet.scbdd.com/; accessed on 15 August 2021). Categorical and numeric values were considered "positive/beneficial" (green) or "negative/harmful" (red) based on the interpretation provided by the server (see Supplementary File 2) [63]. Next, a score was assigned to each compound as follows: 1 for green properties and 0 for red properties [66]. For calculating the ADME/T index, data were then converted to values from 0 to 1 as in Sections 2.4.1 and 2.4.2. Then, the ADME/T indices were subjected to HCA with a heat map graph. Values close to 0 were considered the worst, while those close to 1 were considered the most promising.

\subsection{Risk of Bias Assessment}

The possible sources of bias include the study exclusion/inclusion criteria, chosen database, language, different MD programs used in different studies, and article type selected for this study. The quality of the studies was assessed based on articles that were published in peer-reviewed journals [67].

\subsection{Visual and Statistical Analysis}

A word cloud was generated in the RStudio software "word clouds" package to visualize the most frequently studied EO compounds against SARS-CoV-2 [68]. HCAs with heat map graphs were performed using the toolbox "HeatMapDendrogram" in the OriginPro software (OriginLab Corporation). For the HCA setup, the Euclidean distance and Ward's linkage algorithm were used to hierarchically group the EO compounds and reference drugs into clusters according to their similarity concerning each evaluated parameter: the $\mathrm{BE} / \mathrm{DS}$ regarding specific target proteins, DLI, BSI, and ADME/T index [2,69]. 


\section{Results and Discussion}

\subsection{Main EO Compounds Evaluated against SARS-CoV-2}

In the search for new molecules with the potential to inhibit the coronavirus, studies have focused on plant species already known for their rich composition of bioactive compounds with the potential to impair viral replication or support the treatment of some symptoms of COVID-19, specifically in the reduction of the self-perception of dyspnea and the inhibition of pulmonary ventilation. It has been proposed that many EO compounds reach the respiratory tract by inhalation, mainly due to their volatility and successful use in treating other respiratory tract infections. Consequently, EOs can contribute positively to symptoms such as cough, mucus, nasal congestion, runny nose, or sore throat $[14,70]$.

A word cloud is a visual representation of the frequency and number of words most present in a dataset [68]. Figure 2 illustrates the main EO compounds evaluated in the in silico studies against SARS-CoV-2. Compounds such as thymol, eucalyptol (1,8cineole), carvacrol, limonene, camphene, thymoquinone, and carvone, among others, were widely evaluated against different target proteins of the coronavirus. The most frequent compounds are present mainly in EOs from the Nigella sativa Boiss. species and genus Eucalyptus.

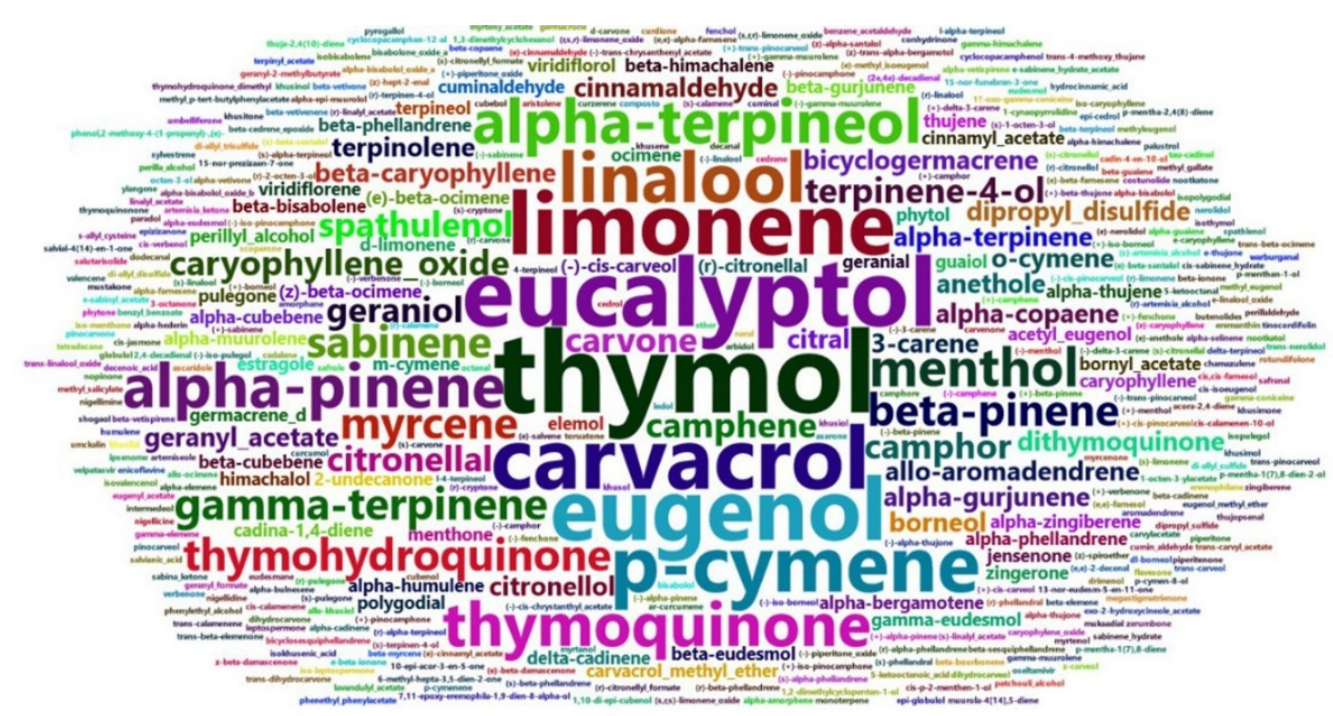

Figure 2. Word cloud identifying the most evaluated essential oil (EO) compounds in molecular docking studies against SARS-CoV-2.

The EO from Eucalyptus globulus Labill. has eucalyptol as its major compound $(52.47 \%)$ [3]. It is an antimicrobial and anti-inflammatory agent, which may play an important role in clinical outcomes in patients with COVID-19 [14,71]. In the study by Li et al. [72], eucalyptol showed protection against influenza A virus (IFV) in mice, attenuating the inflammatory responses. Limonene is also present in this EO, presenting anti-inflammatory and immunomodulatory potential, and it is being considered as a candidate for COVID-19 treatment [73]. Both eucalyptol and limonene are also present in EOs such as Pelargonium graveolens L'Hér. and Citrus limon Osbeck, which showed an inhibitory effect against ACE2 in epithelial cells [56].

Another plant frequently evaluated in studies with anti-SARS-CoV-2 potential $(n=8)$ was black cumin ( $N$. sativa), which is composed mainly of trans-anethole, p-cymene, limonene, carvone, $\alpha$-thujene, thymoquinone (TQ), thymohydroquinone (THQ), dithymoquinone, carvacrol, and $\beta$-pinene $[74,75]$. This composition gives it medicinal potential against neurological and mental diseases, cardiovascular disorders, cancer, diabetes, and inflammatory and viral diseases [76]. There are few reports in the literature about the antiviral action of EOs from N. sativa. However, a study by Labib and Sohrab [77] revealed 
that a plant oil containing thymoquinone showed a reduction in viral infection in a model of murine cytomegalovirus (MCMV).

Thymol, carvacrol, and eugenol are compounds already known for their biological potential. Previously, carvacrol exhibited a significant reduction in lung inflammation in mice with emphysema [78]. In the study by Vimalanathan and Hudson [79], eugenol vapor demonstrated rapid action against the IFV. In the same way, thyme EO, which has a high amount of thymol in its composition, showed antiviral activity against herpes simplex virus type 1 (HSV-1), human rhinoviruses (HRV), and the IFV [80], justifying the interest in evaluating the effectiveness of these compounds against SARS-CoV-2.

\subsection{Selection of EO Compounds}

The binding energy (BE) and docking score (DS) through MD analysis are frequently used as screening parameters since they indicate the stability of the interaction between the compound and target protein considering their binding sites [49,50]. Therefore, the promising EO compounds and the reference drugs were those grouped in the cluster with the highest predicted affinity based on the BE and DS values for each evaluated human and SARS-CoV-2 target protein (Supplementary File 3).

In total, $22 \mathrm{EO}$ compounds were selected for the main protease $\left(\mathrm{M}^{\text {pro }} / 3 \mathrm{CL}^{\text {pro }}\right)(\mathrm{BE}=8$; $\mathrm{DS}=14), 46$ for the spike protein ( $\left.\mathrm{S}^{\mathrm{pro}}\right)(\mathrm{BE}=36$; $\mathrm{DS}=13), 13$ for ACE2 (BE = 7; DS = 6), and 6 for the ACE2-S ${ }^{\text {ro }}$ complex $(\mathrm{BE}=4 ; \mathrm{DS}=2)$ (see Supplementary File 3 (Figures S1-S4)). The compounds clustered by the lowest BE and DS values were also selected for the enzyme transmembrane protease serine type 2 (TMPRSS2) $(\mathrm{BE}=4)$, nonstructural protein 9 RNA binding protein $(\mathrm{BE}=3)$, replicase polyprotein $(\mathrm{BE}=3)$, cathepsin $\mathrm{B}(\mathrm{CatB})$ $(\mathrm{BE}=2)$, cathepsin $\mathrm{L}(\mathrm{CatL})(\mathrm{BE}=5)$, RNA-dependent RNA polymerase (DS = 6), endoribonuclease (DS $=21$ ), and ADP ribose phosphatase $(\mathrm{DS}=16$ ) (see Supplementary File 3 (Figures S5-S11)). In the end, 101 different compounds were screened, of which 94 were EO compounds and 7 were reference drugs (artemisinin, camostat, remdesivir, arbidol, chloroquine, favipiravir, and hydroxychloroquine).

Among the screened compounds, some of them are present in EOs already known for their antiviral potential. $\beta$-caryophyllene, present in the EO of Zataria multiflora Boiss., had a high binding affinity with Mpro (DS: $-7.7 \mathrm{Kcal} / \mathrm{mol}$ ), showing a high similarity with some reference drugs (remdesivir, favipiravir, and hydroxychloroquine). This sesquiterpene showed a selectivity index (SI) of 55.4 with an IC50 of $0.003 \%$, contributing to the antiviral activity against HSV-1 [81]. The EO from Z. multiflora also contains thymol $(-6.9 \mathrm{Kcal} / \mathrm{mol})$ and caryophyllene oxide $(-7 \mathrm{Kcal} / \mathrm{mol})$, which exhibited a high binding affinity to Spro, similar to artemisinin, a reference drug. Furthermore, caryophyllene oxide showed similarity to remdesivir against RP1a and nonstructural protein 9 RNA-binding protein (Supplementary File 3). A previous study revealed that isolated thymol compounds showed 96\% inhibition against the SARS-CoV-2 virus in the Vero E6 cell line [55].

The EO of Eucalyptus bicostata Maiden, Blakely \& Simmonds evaluated against coxsackievirus B3 showed antiviral action at $0.7 \mathrm{mg} / \mathrm{mL}$ (SI: 22.8) [82]. This EO contains eucalyptol, $\alpha$-pinene, limonene, spathulenol, and $\alpha$-eudesmol. In our study, these compounds showed a high affinity for Mpro , ACE2, and CatL, with a high similarity to reference drugs such as hydroxychloroquine, arbidol, and remdesivir. However, eucalyptol did not show expressive BE and DS values for any evaluated target proteins. On the other hand, the EO of Xylopia aethiopica A.Rich. with eucalyptol in its composition exhibited moderate antiviral action against the SARS-CoV-1 and SARS-CoV-2 pseudoviruses [57]. In another study, the EOs of E. globulus and Salvia officinalis O.Bolòs \& Vigo, both containing eucalyptol as the majority compound, showed opposite effects against the H1N1 influenza virus [79].

It is noteworthy that the action of EOs is mainly attributed to their compositional complexity acting synergistically, wherein minority compounds can show higher activity than the majority ones $[13,83,84]$. Furthermore, the antiviral potential of EOs depends on factors concerning the virus, such as the viral load kinetic and viral protein structure. However, the whole mechanism is not fully understood yet, and it is known that the 
most common action mechanism is the direct interaction of the EO with the virus $[13,85]$. Therefore, a better understanding of the promising effects of EOs against SARS-CoV-2 is needed to aid future studies in evaluating possible action pathways of EOs against the virus.

\subsection{Physicochemical, Pharmacokinetic, and Toxicity Properties}

The structural similarity of molecules with known drugs is a widely used approach to discover promising compounds [86]. In our study, drug-likeness and bioactivity scores were used to predict the pharmacological potential of the previously selected compounds. Then, the promising compounds in both parameters were submitted to ADME/T prediction to understand the pharmacokinetics and toxicity parameters.

The DLI was created based on violations of the three rules (Section 2.4.1). EO compounds and reference drugs were considered promising when they presented a DLI equal to or greater than 0.67 (Figure 3), representing the presence of violation in only one of the three rules. Of the total, 62 compounds showed a DLI greater than or equal to 0.67 . Among them, 15 EO compounds had a DLI of 1.0, showing similarity with four reference drugs (artemisinin, arbidol, camostat, and hydroxychloroquine). A DLI of 0.67 was achieved by $43 \mathrm{EO}$ compounds and the reference drug chloroquine, where most of them presented violations within Muegge's rule. Lipinski's, Ghose's, and Muegge's rules are parameters that qualify compounds as possible drugs. For Lipinski's rule of five (RO5), the compound must meet the following criteria: molecular weight $(\mathrm{MW}) \leq 500$, number of hydrogen bond donors $(\mathrm{HBD}) \leq 5$, number of hydrogen bond acceptors $(\mathrm{HBA}) \leq 10, \mathrm{LLogP} \leq 5$, and number of rotatable bonds $(\mathrm{n}-\mathrm{ROTB}) \leq 10$ [87]. For Ghose's rule, the compound must have a LogP value between -0.4 and 5.6, number of atoms ranging from 20 to 70, molecular weight between 160 and $480 \mathrm{~g} / \mathrm{mol}$, and molar refractivity ranging from 40 to 130 [60]. In addition, Muegge's rule utilizes the following criteria: MW between 200 and 600, LogP between -2 and 5 , TSPA $\leq 150$, number of ring $\leq 7$, number of carons $>4$, number of heteroatoms $>1, \mathrm{n}-\mathrm{ROTB} \leq 15, \mathrm{HBD} \leq 5$, and $\mathrm{HBA} \leq 10$ [61].

In the same manner, the BSI was created based on the bioactivity score prediction (Section 2.4.2). The determination of bioactivity allows for the evaluation of the active potential of compounds against the main target proteins of drugs, such as binding to the G protein-coupled receptor (GPCR) ligand and nuclear receptor ligand, ion channel modulation, kinase, protease inhibition, and enzyme activity inhibition. Similar to DLI, compounds with a BSI equal to or greater than 0.67 were considered promising, referring to the active potential (Figure 4). Four clusters were formed with BSI values of $0.67(n=16)$, $0.72(n=27)$, ranging from 0.83 to $0.78(n=17)$, and ranging from 0.94 to $0.89(n=6)$. Of the total, 60 compounds showed potential activity, of which six were reference drugs (artemisinin, arbidol, camostat, remdesivir, chloroquine, and hydroxychloroquine).

After the DLI and BSI analyses, a total of $41 \mathrm{EO}$ compounds and five reference drugs were selected for the next stage. Then, they were evaluated for pharmacokinetic and toxicity properties (ADME/T), which are crucial parameters for the effective selection of high-quality drug candidates (Supplementary File 3).

Concerning absorption properties, the majority of the EO compounds showed good human intestinal absorption (HIA) and Caco-2 permeability, except salvianolic acid and camostat, which showed low HIA. None of the EO compounds appeared as a substrate for P-glycoprotein (P-gp), but some acted as P-gp inhibitors $(n=11)$, including reference drugs (arbidol and camostat). According to Abdallah et al. [88], the P-gp pumps substrates out of the cells in an ATP-dependent mechanism, and the inhibition of P-gp increases the intracellular concentration of xenobiotics. Regarding distribution properties, all compounds, including reference drugs, were positive for blood-brain barrier (BBB). Only six EO compounds (costunolide, eremanthin, isokhusenic acid, rhinocerotinoic acid, salvianic acid, and walburganai) and three references drugs (arbidol, artemisinin, and camostat) showed a volume distribution (VD) out of the ideal range. However, for plasma protein 
binding (PPB), almost all EO compounds and reference drugs exhibited an intermediate distribution $(<90 \%)$.

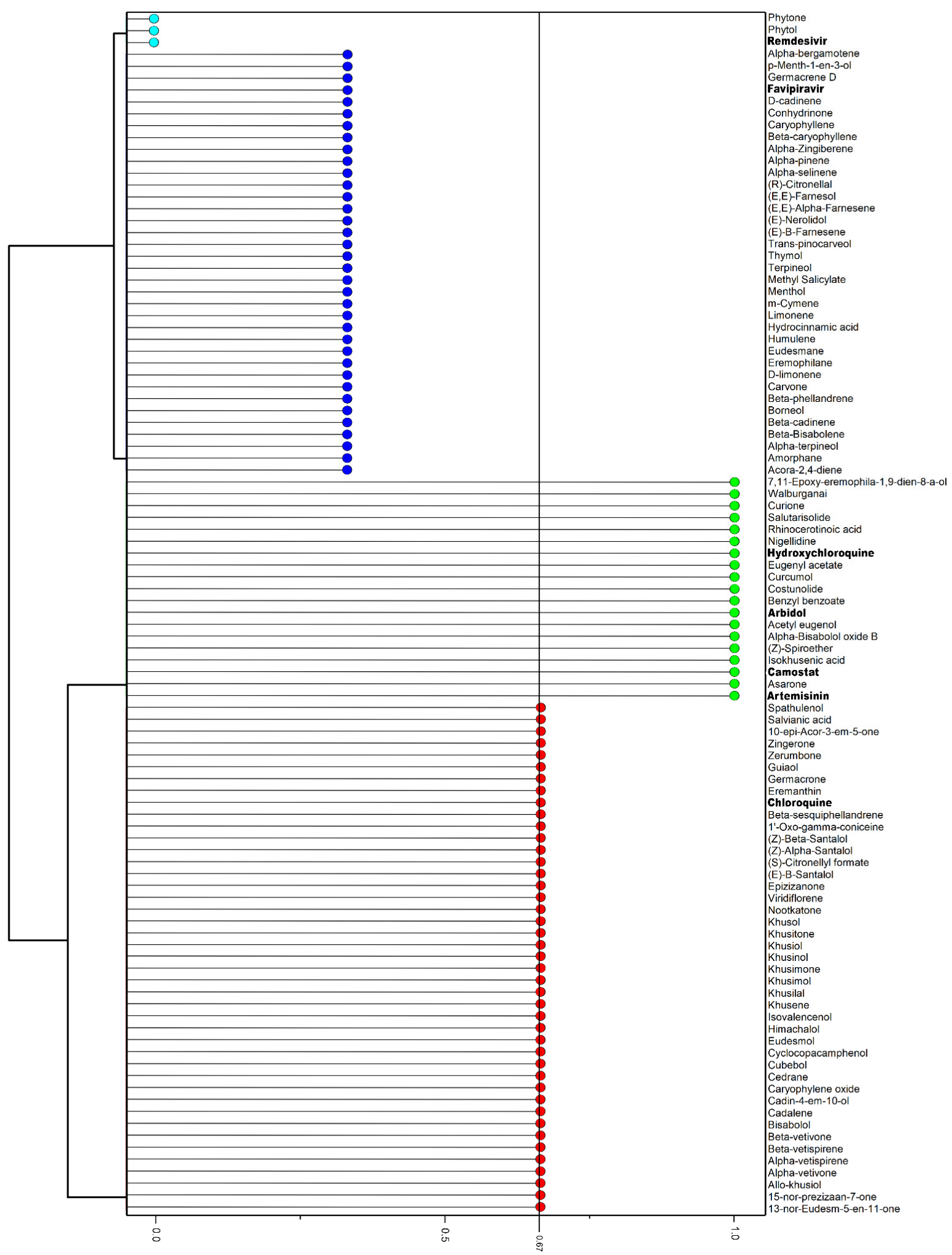

Figure 3. Hierarchical clustering dendrogram of drug likeness index (DLI) of essential oil (EO) compounds and reference drugs (bold) calculated from Lipinski's, Ghose's, and Muegge's rules through Molinspiration (https:/ / www.molinspiration. com/; accessed on 15 August 2021) and SwissADME (http:/ / www.swissadme.ch/; accessed on 15 August 2021) servers. 


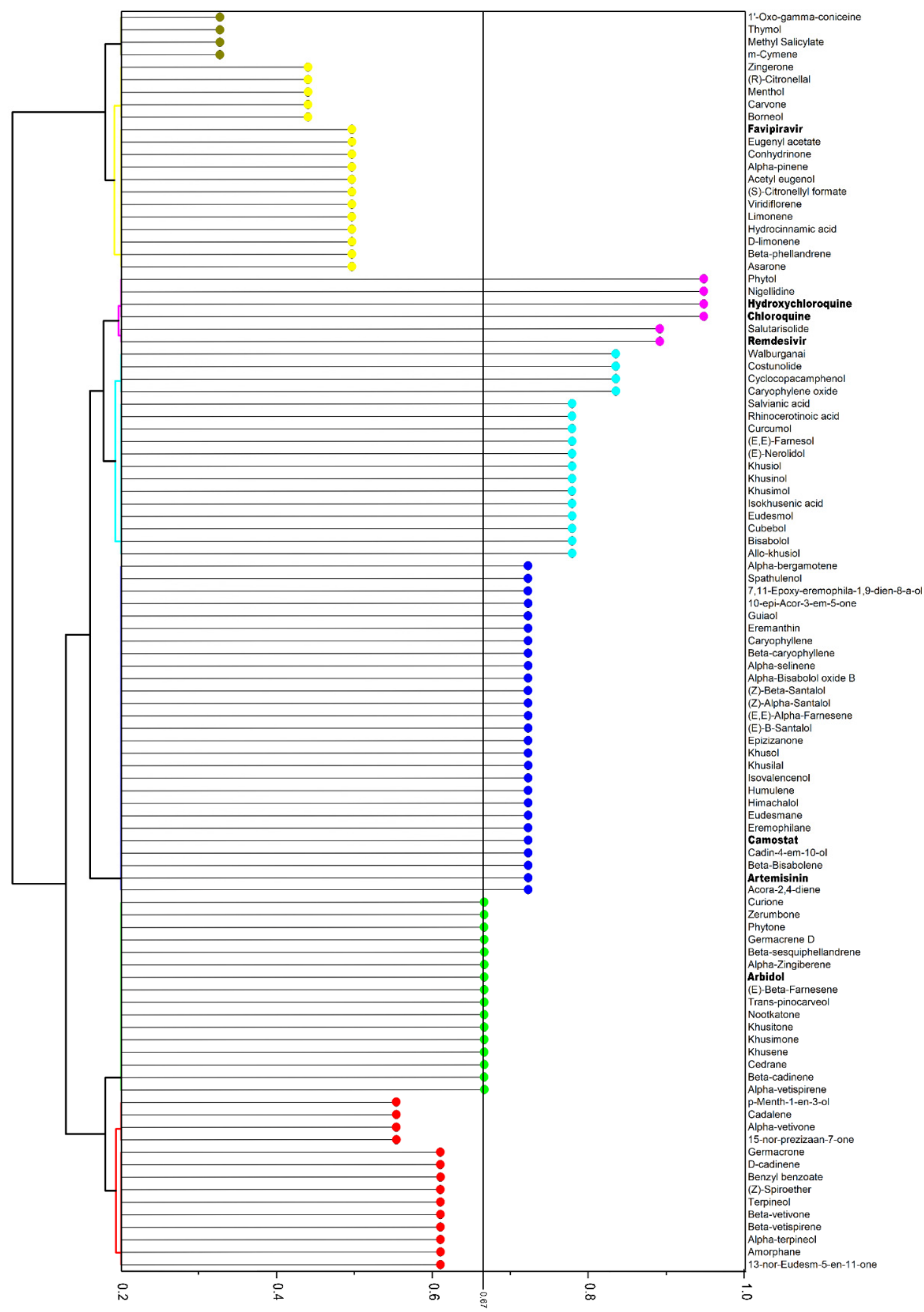

Figure 4. Hierarchical clustering dendrogram of bioactivity score index (BSI) of essential oil (EO) compounds and reference drugs (bold) through the Molinspiration server (https:/ / www.molinspiration.com/; accessed on 15 August 2021).

Regarding metabolism properties, the enzymes of cytochrome $\mathrm{P} 450$ of the liver and gut (CYP1A2, CYP3A4, CYP2C9, CYP2C19, and CYP2D6) are responsible for metabolizing drug molecules by breaking down, absorbing, and eliminating them through bile and 
urine [89]. In our study, only one EO compound (nigellidine) was inhibitory (CYP1A2), while four reference drugs demonstrated this effect as follows: arbidol (CYP1A2, CYP3A4, CYP2C9, CYP2C19, and CYP2D6), artemisinin (CYP1A2), chloroquine (CYP2D6), and hydroxychloroquine (CYP2D6). In contrast, all of the compounds were found to be substrates of at least one enzyme. The metabolization of these compounds maintains a balance of blood concentration. On the contrary, the inhibition increases the compound blood concentration, which can cause adverse effects [90].

Relating to the excretion property, all EO compounds and reference drugs had a short half-life ( $<3 \mathrm{~h}$ ). Concerning toxicity properties, only one EO compound (nigellidine) was a human Ether-a-go-go Related Gene (hERG) blocker and demonstrated LD50 less than $501 \mathrm{mg} / \mathrm{kg}$. The hERG blockers can lead to QT interval prolongation and Torsades de Pointes (TdP) arrhythmia [91].

The reference drugs hydroxychloroquine, chloroquine, arbidol, and camostat also demonstrated the ability to block hERG. Chloroquine is already known as an hERG blocker, and both chloroquine and hydroxychloroquine have been reported as potent QT interval prolongers [92]. None of the EO compounds were mutagenic (Ames). However, two reference drugs (chloroquine and hydroxychloroquine) showed mutagenic properties. For drug-induced liver injury (DILI), six EO compounds (costunolide, eremanthin, khusilal, khusitone, nigellidine, and nootkatone) and three reference drugs (arbidol, camostat, and hydroxychloroquine) demonstrated a potential to damage the liver. A drug that induces DILI can lead to acute liver failure and the need for liver transplantation [93]. According to Adegbola et al. [94], several compounds with antiviral potential were predicted to be probably mutagenic, cytotoxic, and DILI-positive. However, in our study, most EO compounds were potentially safe concerning hERG, Ames, LD50, and DILI.

Through HCA with the heat map graph, $15 \mathrm{EO}$ compounds were grouped by their similarity, referring to the highest values of the ADME/T index, representing compounds with positive/benefit indices related to absorption, distribution, metabolism, excretion, and toxicity parameters (Figure 5). It is noteworthy that no reference drug showed this potential. Accordingly, these compounds were considered promising drug candidates for further evaluation of their anti-SARS-CoV-2 action through in vitro and in vivo studies. Likewise, such compounds may be indicators of EOs with potential antiviral activity against SARS-CoV-2.

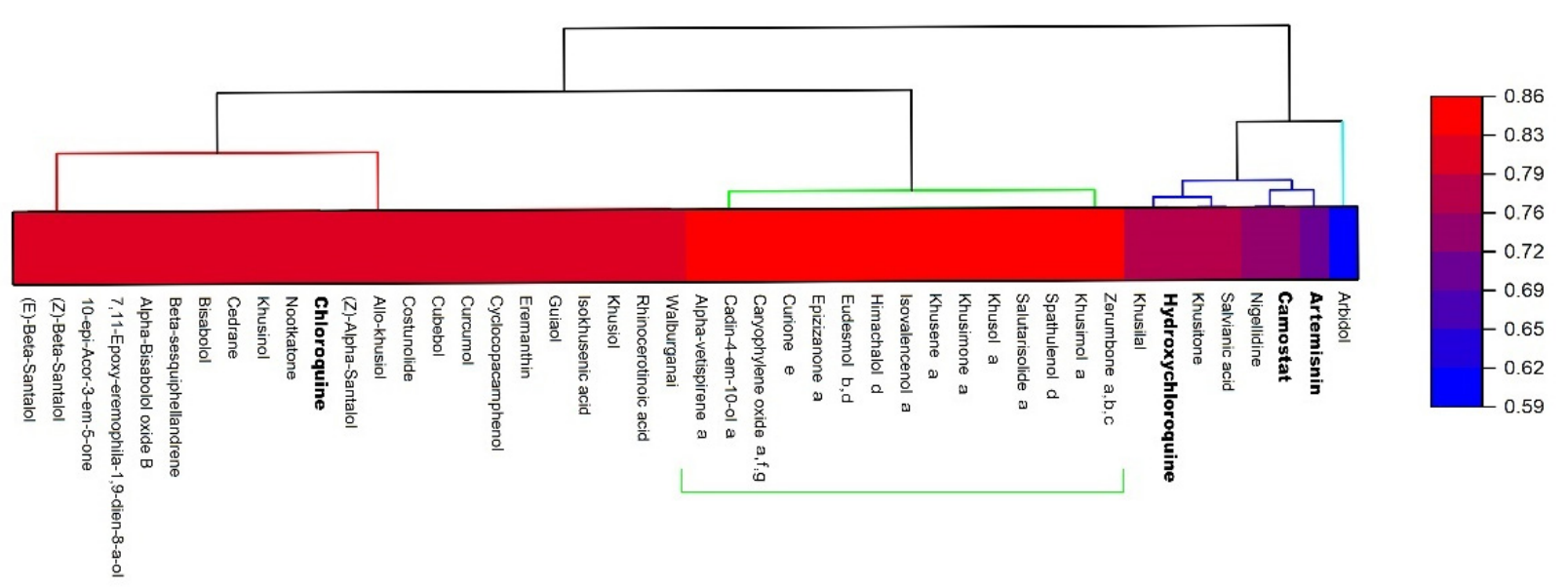

Figure 5. Hierarchical clustering dendrogram and heat map for the ADME/T index of essential oil (EO) compounds and reference drugs (bold) against SARS-CoV-2. Where: a Spike protein (Spro); b Angiotensin-converting enzyme-2 (ACE2); c ACE2-Spro complex; d Mpro; e Endoribonuclease (EndoU); f Nonstructural protein 9 RNA binding protein; $g$ Replicase polyprotein. 


\subsection{Main Target Proteins for SARS-CoV-2 Inactivation}

Most of the compounds with potential anti-SARS-CoV-2 action had the spike protein $\left(\mathrm{S}^{\mathrm{pro}}\right)(n=11)$ as their main target (Figure 5$)$. This protein is abundant on the SARS-CoV2 surface and is responsible for mediating the entry of the virus into the human body through its binding to the human cell receptor ACE2 [95]. Compounds such as eudesmol and zerumbone have been shown to have a great affinity for ACE2. Several studies have evaluated both the Spro and ACE2 as potential alternatives to inhibit viral infection. In the study by Sharbidre et al. [40], zerumbone demonstrated a great affinity for the SARS-CoV-2 spike protein $\left(\mathrm{S}^{\text {pro }}\right)$ and human cell receptor ACE2 complex.

The main protease $\left(\mathrm{M}^{\mathrm{pro}} / 3 \mathrm{CL}^{\mathrm{pro}}\right)$ is a cysteine protease that plays a critical role in the viral replication cycle $[35,96]$. Moreover, this target protein is already used to identify potential anticoronavirus inhibitors [97,98]. Eudesmol, himachalol, and spathulenol were considered promising EO compounds regarding this protein (Figure 5). Caryophyllene oxide showed a high affinity for the $\mathrm{S}^{\text {pro }}$, but also for RP1a and nonstructural protein 9 RNA binding protein. Moreover, curione was promising for endoribonuclease (EndoU). This protein limits the host's immune response and is necessary for effective SARS-CoV-2 replication [99].

\subsection{Botanical Sources of EOs with Potential Anti-SARS-CoV-2 Activity}

EOs and their compounds have attracted particular attention for their reported beneficial properties such as antimicrobial, antioxidant, anti-inflammatory, antifungal, and antiviral properties [100]. Their antiviral properties have been increasingly researched due to the current COVID-19 pandemic scenario worldwide. According to Queiroz de Oliveira et al. [101], the pharmaceutical and food industries are highly interested in finding EOs with potential anti-SARS-CoV-2 activity. However, in vitro and in vivo studies about this subject are scarce in the literature. In this context, our findings are helpful to identify promising botanical sources for obtaining effective EOs against SARS-CoV-2 and other viral infections.

Eudesmol is present in large amounts in EOs extracted from plants such as Neocallitropsis pancheri Laub., Atractylodes lancea Kitam., and Melaleuca leucadendra Cheel [102,103]. The antiviral action of this compound was observed against herpes simplex virus type 1 (HSV-1) with an IC50 of $6 \mu \mathrm{g} / \mathrm{mL}$ and an antiviral selectivity index (SI) of 5.8 [83]. In the study by Senthil Kumar et al. [56], eudesmol was present in the EO from P. graveolens and showed significant inhibitory effects of ACE2 on epithelial cells. This compound has been suggested for incorporation into biodegradable food packaging to mitigate viral cross-contamination [101].

Caryophyllene oxide is reported in the EO from the genera Cinnamomum verum J.Presl, Syzygium aromaticum Merr. \& L.M.Perry, M. officinalis, Zataria multiflora Boiss., and Eucaliptos [104-106]. The EO from Z. multiflora, with caryophyllene oxide in its composition, showed satisfactory antiviral action against HSV-1 [81], which was also observed for spathulenol, a majority compound in Eucalyptus polybractea F.Muell. ex R.T.Baker, Baccharis dracunculifolia DC., and varieties of Eugenia brasiliensis Cambess [81,103,107].

The species Zingiber zerumbet Triboun \& K.Larsen, together with those belonging to the genus Curcuma, are known for their vast bioactive potential, containing compounds such as curione and zerumbone [108-110]. The antiviral action of EOs obtained from plants from the Curcuma genus is little reported in the literature. Maurya et al. [111] reported the effectiveness of EO from Curcuma longa Velay., Pandrav., J.K.George \& Varapr. against papaya ringspot virus (PRSV). The same potential was found for zerumbone against the Epstein-Barr Virus (EBV) [112].

The EO of Cedrus libani A.Rich, rich in himachalol, showed action against HSV-1 [113]. Cadin-4-en-10-ol (alpha-Cadinol) is predominant in plants from the Eugenia genus such as E. biflora DC. and E. brasiliensis [107]. Salutarisolide was found in large amounts in the EO from Warburgia salutaris (G.Bertol.) Chiov. [114]. However, there are no reports about the 
antiviral effects of either cadin-4-en-10-ol (alpha-cadinol) nor salutarisolide at the present moment.

Most of the promising compounds found in the present study were significantly identified in vetiver EO (Chrysopogon zizanioides Roberty or Vetiveria zizanoides Nash) as alpha-vetispirene, isovalencenol, khusene, khusimol, khusimone, khusol, and epizizanone [103,115-117]. This EO has been reported as antimicrobial [118], antifungal [119], anxiolytic [120], antioxidant, and anti-inflammatory [121]. To our knowledge, there is only one study reporting the antiviral action of this EO. Ralambondrainy et al. [85] observed no antiviral activity in vitro of $V$. zizanoides at $29.4 \mu \mathrm{g} / \mathrm{mL}$ against the Ross River virus (RRV). Nevertheless, the maximum non-cytotoxic concentration of the EO from $V$. zizanoides was not determined, and thus, it was not tested, which may have contributed to their non-significant antiviral action results.

The antiviral action of EOs strongly depends on their composition, concentration, and mechanism of action against the virus [13], as well as aspects regarding the virus such as the viral load kinetic and viral protein structure. Despite this fact, no study has evaluated the antiviral action of the promising EO compounds identified in the present study against SARS-CoV-2, indicating a clear need for future studies in this subject.

\section{Review Limitations}

This review aimed to conduct a survey of the literature on the potential of EO compounds against the SARS-CoV-2 virus; however, it presents some limitations. As expected, because the COVID-19 pandemic is recent, most of the data retrieved were from in silico studies against the main target proteins of the virus. In silico data have great value in the virtual screening of new drugs. However, they can be obtained by different methods [122], so data from in silico studies must be validated through in vitro and in vivo approaches, which are imperative for assessing the antiviral potential of EOs against the SARS-CoV-2 virus. Furthermore, our study was not registered in PROSPERO. This is due to the unavoidable need to find new, effective compounds against SARS-CoV-2 and the fact that recent reports related to COVID-19 are being published daily. Despite the matters mentioned above, this study can be updated anytime by incorporating new data and relevant information that can help to better understand the potential of EOs against SARS-CoV-2, presenting an adequate record of the research.

\section{Conclusions and Future Perspectives}

Ninety-four EO compounds showed a high binding affinity against 11 target proteins. Amongst them, 15 (alpha-vetispirene, cadin-4-em-10-ol, caryophyllene oxide, eudesmol, himachalol, isovalencenol, khusene, khusimol, khusimone, khusol, epizizanone, salutarisolide, zerumbone, curione, and spathulenol) were considered the most promising EO compounds against SARS-CoV-2 based on their physicochemical, pharmacokinetic, and toxicity properties. Considering these findings, several plants were suggested as EO sources with potential anti-SARS-CoV-2, such as M. officinalis, Z. multiflora, E. brasiliensis, Z. zerumbet, C. libani, and $V$. zizanoides. The EO from $V$. zizanoides showed the highest number of compounds with anti-SARS-CoV-2 potential and the Spro as their target protein. It is noteworthy that the data regarding the action of EOs and their isolated compounds against the COVID-19 virus are still recent and preliminary. Therefore, further in vitro and in vivo studies are needed to determine the antiviral activity of the compounds and elucidate their possible mechanisms of action. Our findings are helpful to aid further in vitro and in vivo studies to identify effective EOs and guide the development of novel formulations against COVID-19 for different food, pharmaceutical, cosmetic, and medical applications.

Supplementary Materials: The following are available online at https: / www.mdpi.com/article / 10.3390/ph14111138/s1, Supplementary File 1: PRISMA 2020 Checklist; Supplementary File 2: Pharmacokinetic and toxicology properties of essential oil (EO) compounds and reference drugs obtained through the ADMETlab server; Supplementary File 3: Hierarchical clustering dendrogram 
and heat map for essential oil compounds and reference drugs against the main target proteins of SARS-CoV-2.

Author Contributions: L.T.N.: conceptualization and writing—original draft; M.L.G.M.: conceptualization, writing — review, and editing; D.G.: resources, investigation, writing-review, and editing; C.A.C.-J.: funding acquisition, project administration, supervision, writing-review, and editing. All authors have read and agreed to the published version of the manuscript.

Funding: This research was funded by Fundação de Amparo à Pesquisa do Estado do Rio de Janeiro (FAPERJ) Brazil—grant number [E-26/203.049/2017, E-26/010.000148/2020, and E-26/201.790/2020], the Conselho Nacional de Desenvolvimento Científico e Tecnológico (CNPq)—grant number [313119/ 2020-1 and 163480/2020-6] and the Coordenação de Aperfeiçoamento de Pessoal de Nível Superior (CAPES) Brazil—grant number [88887.518752/2020-00].

Institutional Review Board Statement: Not applicable.

Informed Consent Statement: Not applicable.

Data Availability Statement: Data sharing not applicable.

Conflicts of Interest: The authors declare no conflict of interest and no competing financial interest.

\section{References}

1. Sharma, S.; Barkauskaite, S.; Jaiswal, A.K.; Jaiswal, S. Essential oils as additives in active food packaging. Food Chem. 2021, 343, 128403. [CrossRef] [PubMed]

2. Galvan, D.; Effting, L.; Neto, L.T.; Conte-Junior, C.A. An overview of research of essential oils by self-organizing maps: A novel approach for meta-analysis study. Compr. Rev. Food Sci. Food Saf. 2021, 20, 1541-4337. [CrossRef]

3. Panikar, S.; Shoba, G.; Arun, M.; Sahayarayan, J.J.; Nanthini, A.U.R.; Chinnathambi, A.; Alharbi, S.A.; Nasif, O.; Kim, H.-J. Essential oils as an effective alternative for the treatment of COVID-19: Molecular interaction analysis of protease (Mpro) with pharmacokinetics and toxicological properties. J. Infect. Public Health 2021, 14, 601-610. [CrossRef] [PubMed]

4. WHO. WHO Coronavirus (COVID-19) Dashboard. Available online: https:// covid19. who.int (accessed on 4 November 2021).

5. Rees, E.M.; Nightingale, E.S.; Jafari, Y.; Waterlow, N.R.; Clifford, S.; Pearson, C.A.B.; Jombart, T.; Procter, S.R.; Knight, G.M.; CMMID Working Group. COVID-19 length of hospital stay: A systematic review and data synthesis. BMC Med. 2020, 18, 270. [CrossRef]

6. CDC About Variants of the Virus that Causes COVID-19. Available online: https://www.cdc.gov/coronavirus/2019-ncov/ variants / variant.html (accessed on 29 July 2021).

7. Dagan, N.; Barda, N.; Kepten, E.; Miron, O.; Perchik, S.; Katz, M.A.; Hernán, M.A.; Lipsitch, M.; Reis, B.; Balicer, R.D. BNT162b2 mRNA COVID-19 vaccine in a nationwide mass vaccination setting. N. Engl. J. Med. 2021, 384, 1412-1423. [CrossRef] [PubMed]

8. Vellingiri, B.; Jayaramayya, K.; Iyer, M.; Narayanasamy, A.; Govindasamy, V.; Giridharan, B.; Ganesan, S.; Venugopal, A.; Venkatesan, D.; Ganesan, H.; et al. COVID-19: A promising cure for the global panic. Sci. Total Environ. 2020, $725,138277$. [CrossRef] [PubMed]

9. Gowrishankar, S.; Muthumanickam, S.; Kamaladevi, A.; Karthika, C.; Jothi, R.; Boomi, P.; Maniazhagu, D.; Pandian, S.K. Promising phytochemicals of traditional Indian herbal steam inhalation therapy to combat COVID-19-An in silico study. Food Chem. Toxicol. 2021, 148, 111966. [CrossRef]

10. Duda-Chodak, A.; Lukasiewicz, M.; Zięć, G.; Florkiewicz, A.; Filipiak-Florkiewicz, A. COVID-19 pandemic and food: Present knowledge, risks, consumers fears and safety. Trends Food Sci. Technol. 2020, 105, 145-160. [CrossRef]

11. Paraskevis, D.; Kostaki, E.; Magiorkinis, G.; Panayiotakopoulos, G.; Sourvinos, G.; Tsiodras, S. Full-genome evolutionary analysis of the novel corona virus $(2019-\mathrm{nCoV})$ rejects the hypothesis of emergence as a result of a recent recombination event. Infect. Genet. Evol. 2020, 79, 104212. [CrossRef]

12. Sobrinho, A.C.N.; de Morais, S.M.; Marinho, M.M.; de Souza, N.V.; Lima, D.M. Antiviral activity on the Zika virus and larvicidal activity on the Aedes spp. of Lippia alba essential oil and $\beta$-caryophyllene. Ind. Crop. Prod. 2021, 162, 113281. [CrossRef]

13. Ma, L.; Yao, L. Antiviral effects of plant-derived essential oils and their components: An updated review. Molecules 2020, $25,2627$. [CrossRef]

14. Valussi, M.; Antonelli, M.; Donelli, D.; Firenzuoli, F. Appropriate use of essential oils and their components in the management of upper respiratory tract symptoms in patients with COVID-19. J. Herb. Med. 2021, 28, 100451. [CrossRef] [PubMed]

15. Asif, M.; Saleem, M.; Saadullah, M.; Yaseen, H.S.; Al Zarzour, R. COVID-19 and therapy with essential oils having antiviral, anti-inflammatory, and immunomodulatory properties. Inflammopharmacology 2020, 28, 1153-1161. [CrossRef] [PubMed]

16. Tshibangu, D.S.T.; Matondo, A.; Lengbiye, E.M.; Inkoto, C.L.; Ngoyi, E.M.; Kabengele, C.N.; Bongo, G.N.; Gbolo, B.Z.; Kilembe, J.T.; Mwanangombo, D.T.; et al. Possible effect of aromatic plants and essential oils against COVID-19: Review of their antiviral activity. J. Complement. Altern. Med. Res. 2020, 11, 10-22. [CrossRef]

17. Ojah, E.O. Exploring essential oils as prospective therapy against the ravaging Coronavirus (SARS-CoV-2). Iberoam. J. Med. 2020, 4, 322-330. [CrossRef] 
18. Page, M.J.; McKenzie, J.E.; Bossuyt, P.M.; Boutron, I.; Hoffmann, T.C.; Mulrow, C.D.; Shamseer, L.; Tetzlaff, J.M.; Akl, E.A.; Brennan, S.E.; et al. The PRISMA 2020 statement: An updated guideline for reporting systematic reviews. BMJ 2021, $372, \mathrm{n} 71$. [CrossRef] [PubMed]

19. Fabbri, S.; Hernandes, E.; Di Thommazo, A.; Belgamo, A.; Zamboni, A.; Silva, C. Managing literature reviews information through visualization. In Proceedings of the 14th International Conference on Enterprise Information Systems, Wroclaw, Poland, 28 June-1 July 2012; pp. 36-45. [CrossRef]

20. Aljabal, G.A.; Alsaffar, D.F.; Yaseen, A. In silico molecular docking studies of medicinal arabic plant-based bioactive compounds as a promising drug candidate against COVID-19. Int. J. Innov. Sci. Res. Technol. 2020, 5, 876-896.

21. Altayeb, H.; Bouslama, L.; Abdulhakimc, J.A.; Chaieb, K.; Baothman, O.; Zamzami, M. Potential activity of a selected natural compounds on SARS-CoV-2 RNA-dependent-RNA polymerase, and binding affinity of the receptor-binding domain (RBD). Res. Sq. 2020. [CrossRef]

22. Da Silva, J.K.R.; Figueiredo, P.L.B.; Byler, K.G.; Setzer, W.N. Essential oils as antiviral agents, potential of essential oils to treat SARS-CoV-2 infection: An in-silico investigation. Int. J. Mol. Sci. 2020, 21, 3426. [CrossRef]

23. De Jesus, M.; Gaza, J.T.; Junio, H.; Nellas, R. Molecular docking studies of aromatherapy oils against SARS-CoV-2 a preprint. ChemRxiv 2020. [CrossRef]

24. Dwarka, D.; Agoni, C.; Mellem, J.; Soliman, M.E.; Baijnath, H. Identification of potential SARS-CoV-2 inhibitors from South African medicinal plant extracts using molecular modelling approaches. South Afr. J. Bot. 2020, 133, 273-284. [CrossRef] [PubMed]

25. Gurung, A.B.; Ali, M.A.; Lee, J.; Farah, M.A.; Al-Anazi, K.M. Unravelling lead antiviral phytochemicals for the inhibition of SARS-CoV-2 Mpro enzyme through in silico approach. Life Sci. 2020, 255, 117831. [CrossRef]

26. Thuy, B.T.P.; My, T.T.A.; Hai, N.T.T.; Hieu, L.T.; Hoa, T.T.; Loan, H.T.P.; Triet, N.T.; Van Anh, T.T.; Quy, P.T.; Van Tat, P.; et al. Investigation into SARS-CoV-2 resistance of compounds in garlic essential oil. ACS Omega 2020, 5, 8312-8320. [CrossRef] [PubMed]

27. Ibrahim, M.A.; Abdelrahman, A.H.; Hussien, T.A.; Badr, E.A.; Mohamed, T.A.; El-Seedi, H.R.; Pare, P.W.; Efferth, T.; Hegazy, M.-E.F. In silico drug discovery of major metabolites from spices as SARS-CoV-2 main protease inhibitors. Comput. Biol. Med. 2020, 126, 104046. [CrossRef] [PubMed]

28. Istifli, E.S.; Şihoğlu Tepe, A.; Sarikürkcü, C.; TEPE, B. Interaction of certain monoterpenoid hydrocarbons with the receptor binding domain of 2019 novel coronavirus (2019-nCoV), transmembrane serine protease 2 (TMPRSS2), cathepsin B, and cathepsin $\mathrm{L}$ (CatB/L) and their pharmacokinetic properties. Turk. J. Boil. 2020, 44, 242-264. [CrossRef] [PubMed]

29. Krishnasamy, R.; Baba, M.; Bharath, M.V.; Phuntsho, J.; Arunachalam, D.; Natarajan, K.; Ramasamy, M. In silico analysis of active compounds from siddha herbal infusion of Ammaiyar Koondhal Kudineer (Akk) against SARS-CoV-2 spike protein and its ACE2 receptor complex. SSRN Electron. J. 2020. [CrossRef]

30. Kulkarni, S.A.; Nagarajan, S.K.; Ramesh, V.; Palaniyandi, V.; Selvam, S.P.; Madhavan, T. Computational evaluation of major components from plant essential oils as potent inhibitors of SARS-CoV-2 spike protein. J. Mol. Struct. 2020, 1221, 128823. [CrossRef]

31. My, T.T.A.; Loan, H.T.P.; Hai, N.T.T.; Hieu, L.T.; Hoa, T.T.; Thuy, B.T.P.; Quang, D.T.; Triet, N.T.; Van Anh, T.T.; Dieu, N.T.X.; et al. Evaluation of the inhibitory activities of COVID-19 of melaleuca cajuputi oil using docking simulation. ChemistrySelect 2020, 5, 6312-6320. [CrossRef]

32. Paul, A.; Bondhon, T.A.; Afrose, S.; Hasan, A.; Jannat, K.; Paul, A.; Jahan, R.; Rahmatullah, M. In silico binding studies with compounds present in essential oil of Tasmannia lanceolata leaves to 3C-like protease of SARS-CoV-2. J. Med. Plants Stud. 2020, 8, 108-116. [CrossRef]

33. Rolta, R.; Salaria, D.; Kumar, V.; Sourirajan, A.; DEV, K. Phytocompounds of Rheum emodi, Thymus serpyllum and Artemisia annua inhibit COVID-19 binding to ACE2 receptor: In silico approach. Curr. Pharmacol. Rep. 2021, 7, 135-149. [CrossRef]

34. Rout, J.; Swain, B.C.; Tripathy, U. In silico investigation of spice molecules as potent inhibitor of SARS-CoV-2. J. Biomol. Struct. Dyn. 2020, 1-15. [CrossRef]

35. Salim, B.; Noureddine, M. Identification of compounds from nigella sativa as new potential inhibitors of 2019 novel coronasvirus (COVID-19): Molecular docking study. ChemRxiv 2020. [CrossRef]

36. Shaikh, Y.I.; Shaikh, V.S.; Ahmed, K.; Nazeruddin, G.M.; Pathan, H.M. The revelation of various compounds found in Nigella sativa L. (Black Cumin) and their possibility to inhibit COVID-19 infection based on the molecular docking and physical properties. Eng. Sci. 2020, 11, 31-35. [CrossRef]

37. Santra, S.; Das, S.G.; Halder, S.K.; Ghosh, K.; Banerjee, A.; Panda, A.K.; Mondal, K.C. Structure-based assortment of herbal analogues against spike protein to restrict COVID-19 entry through hACE2 receptor: An in-silico approach. Acta Biol. Szeged. 2021, 64, 159-171. [CrossRef]

38. Mohideen, A.K.S. Molecular docking analysis of phytochemical thymoquinone as a therapeutic agent on SARS-CoV-2 envelope protein. Biointerface Res. Appl. Chem. 2020, 11, 8389-8401. [CrossRef]

39. Prasanth, D.S.N.B.K.; Murahari, M.; Chandramohan, V.; Bhavya, G.; Rao, A.L.; Panda, S.P.; Rao, G.S.N.K.; Chakravarthi, G.; Teja, N.; Rani, P.S.; et al. In-silico strategies of some selected phytoconstituents from Melissa officinalis as SARS-CoV-2 main protease and spike protein (COVID-19) inhibitors. Mol. Simul. 2021, 47, 457-470. [CrossRef]

40. Sharbidre, A.; Dhage, P.; Duggal, H.; Meshram, R. In silico investigation of Tridax procumbens phyto-constituents against SARS-CoV-2 infection. Biointerface Res. Appl. Chem. 2021, 11, 12120-12148. [CrossRef] 
41. Mahmud, S.; Paul, G.; Afroze, M.; Islam, S.; Gupt, S.; Razu, M.; Biswas, S.; Zaman, S.; Uddin, S.; Khan, M.; et al. Efficacy of phytochemicals derived from Avicennia officinalis for the management of COVID-19: A combined in silico and biochemical study. Molecules 2021, 26, 2210. [CrossRef] [PubMed]

42. Mehmood, A.; Khan, S.; Khan, S.; Ahmed, S.; Ali, A.; Xue, M.; Ali, L.; Hamza, M.; Munir, A.; Rehman, S.U.; et al. In silico analysis of quranic and prophetic medicinals plants for the treatment of infectious viral diseases including corona virus. Saudi J. Biol. Sci. 2021, 28, 3137-3151. [CrossRef]

43. Pandey, P.; Khan, F.; Mazumder, A.; Rana, A.K.; Srivastava, Y. Inhibitory potential of dietary phytocompounds of nigella sativa against key targets of novel coronavirus (COVID-19). Indian J. Pharm. Educ. Res. 2021, 55, 190-197. [CrossRef]

44. Kumar, A.; Choudhir, G.; Shukla, S.K.; Sharma, M.; Tyagi, P.; Bhushan, A.; Rathore, M. Identification of phytochemical inhibitors against main protease of COVID-19 using molecular modeling approaches. J. Biomol. Struct. Dyn. 2021, 39, 3760-3770. [CrossRef]

45. Abdelli, I.; Hassani, F.; Brikci, S.B.; Ghalem, S. In silico study the inhibition of angiotensin converting enzyme 2 receptor of COVID-19 by Ammoides verticillata components harvested from Western Algeria. J. Biomol. Struct. Dyn. 2020, 39, 3263-3276. [CrossRef]

46. Duru, C.E.; Duru, I.A.; Adegboyega, A.E. In silico identification of compounds from Nigella sativa seed oil as potential inhibitors of SARS-CoV-2 targets. Bull. Natl. Res. Cent. 2021, 45, 57. [CrossRef]

47. Thakkar, S.S.; Shelat, F.; Thakor, P. Magical bullets from an indigenous Indian medicinal plant Tinospora cordifolia: An in silico approach for the antidote of SARS-CoV-2. Egypt. J. Pet. 2021, 30, 53-66. [CrossRef]

48. Yabrir, B.; Belhassan, A.; Lakhlifi, T.; Salgado, M.G.; Bouachrine, M.; Munoz, C.P.; Gerli, C.L.; Ramirez, T.R. Minor composition compounds of algerian herbal medicines as inhibitors of SARS-CoV-2 main protease: Molecular docking and admet properties prediction. J. Chil. Chem. Soc. 2021, 65, 5067-5074. [CrossRef]

49. Yadalam, P.K.; Varatharajan, K.; Rajapandian, K.; Chopra, P.; Arumuganainar, D.; Nagarathnam, T.; Sohn, H.; Madhavan, T. Antiviral essential oil components against SARS-CoV-2 in pre-procedural mouth rinses for dental settings during COVID-19: A computational study. Front. Chem. 2021, 9, 86. [CrossRef]

50. Yunus, G. Herbal compounds from Syzygium aromaticum and Cassia acutifolia as a shield against SARS-CoV-2 Mpro: A molecular docking approach. Biointerface Res. Appl. Chem. 2021, 11, 14853-14865. [CrossRef]

51. Zígolo, M.A.; Goytia, M.R.; Poma, H.R.; Rajal, V.B.; Irazusta, V.P. Virtual screening of plant-derived compounds against SARSCoV-2 viral proteins using computational tools. Sci. Total Environ. 2021, 781, 146400. [CrossRef]

52. Sharma, A.D.; Kaur, I. Molecular docking and pharmacokinetic screening of eucalyptol (1,8 cineole) from eucalyptus essential oil against SARS-CoV-2. Not. Sci. Biol. 2020, 12, 536-545. [CrossRef]

53. Dev, S.A.; Kaur, I. Bioactive molecules from eucalyptus essential oil as potential inhibitors of COVID 19 corona virus infection by molecular docking studies. Kragujev. J. Sci. 2020, 42, 29-43. [CrossRef]

54. Sharma, A.D. Eucalyptol (1,8 cineole) from eucalyptus essential oil a potential inhibitor of COVID 19 corona virus infection by molecular docking studies. Preprints 2020. [CrossRef]

55. Seadawy, M. In vitro: Natural compounds (thymol, carvacrol, hesperidine, and thymoquinone) against SARS-CoV-2 strain isolated from egyptian patients. bioRxiv 2020. [CrossRef]

56. Kumar, K.J.S.; Vani, M.G.; Wang, C.-S.; Chen, C.-C.; Chen, Y.-C.; Lu, L.-P.; Huang, C.-H.; Lai, C.-S.; Wang, S.-Y. Geranium and lemon essential oils and their active compounds downregulate angiotensin-converting enzyme 2 (ACE2), a SARS-CoV-2 spike receptor-binding domain, in epithelial cells. Plants 2020, 9, 770. [CrossRef] [PubMed]

57. Melo, C.; Perdomo, R.; Yerima, F.; Mahoney, O.; Cornejal, N.; Alsaidi, S.; Coron, S.; Bonnaire, T.; Zhang, S.; Zydowsky, T.; et al. Antioxidant, antibacterial, and anti-SARS-CoV Activity of commercial products of Xylopia (Xylopia aethiopica). J. Med. Act. Plants 2021, 10, 11.

58. Ahmad, H.; Ahmad, S.; Shah, S.A.A.; Latif, A.; Ali, M.; Khan, F.A.; Tahir, M.N.; Shaheen, F.; Wadood, A.; Ahmad, M. Antioxidant and anticholinesterase potential of diterpenoid alkaloids from Aconitum heterophyllum. Bioorganic Med. Chem. 2017, 25, 3368-3376. [CrossRef] [PubMed]

59. Gu, W.; Li, Q.; Li, Y. Law and mechanism analysis of biodegradability of polychlorinated naphthalenes based on principal component analysis, QSAR models, molecular docking and molecular dynamics simulation. Chemosphere 2020, $243,125427$. [CrossRef]

60. Ghose, A.K.; Viswanadhan, V.N.; Wendoloski, J.J. A knowledge-based approach in designing combinatorial or medicinal chemistry libraries for drug discovery. 1. A qualitative and quantitative characterization of known drug Databases. J. Comb. Chem. 1999, 1, 55-68. [CrossRef]

61. Muegge, I.; Heald, S.L.; Brittelli, D. Simple selection criteria for drug-like chemical matter. J. Med. Chem. 2001, 44, 1841-1846. [CrossRef]

62. Khan, T.; Dixit, S.; Ahmad, R.; Raza, S.; Azad, I.; Joshi, S.; Khan, A.R. Molecular docking, PASS analysis, bioactivity score prediction, synthesis, characterization and biological activity evaluation of a functionalized 2-butanone thiosemicarbazone ligand and its complexes. J. Chem. Biol. 2017, 10, 91-104. [CrossRef]

63. Natesh, J.; Mondal, P.; Penta, D.; Salam, A.A.A.; Meeran, S.M. Culinary spice bioactives as potential therapeutics against SARS-CoV-2: Computational investigation. Comput. Biol. Med. 2021, 128, 104102. [CrossRef] 
64. Azad, I.; Jafri, A.; Khan, T.; Akhter, Y.; Arshad, M.; Hassan, F.; Ahmad, N.; Khan, A.R.; Nasibullah, M. Evaluation of pyrrole-2,3dicarboxylate derivatives: Synthesis, DFT analysis, molecular docking, virtual screening and in vitro anti-hepatic cancer study. $J$. Mol. Struct. 2019, 1176, 314-334. [CrossRef]

65. Abdelrheem, D.A.; Rahman, A.A.; Elsayed, K.N.; El-Mageed, H.A.; Mohamed, H.S.; Ahmed, S.A. Isolation, characterization, in vitro anticancer activity, dft calculations, molecular docking, bioactivity score, drug-likeness and admet studies of eight phytoconstituents from brown alga sargassum platycarpum. J. Mol. Struct. 2021, 1225, 129245. [CrossRef]

66. Guan, L.; Yang, H.; Cai, Y.; Sun, L.; Di, P.; Li, W.; Liu, G.; Tang, Y. ADMET-score-a comprehensive scoring function for evaluation of chemical drug-likeness. Med. Chem. Comm. 2019, 10, 148-157. [CrossRef]

67. Zabidi, M.S.; Abu Bakar, R.; Musa, N.; Mustafa, S.; Yusuf, W.N.W. Population pharmacokinetics of colistin methanesulfonate sodium and colistin in critically Ill patients: A systematic review. Pharmaceuticals 2021, 14, 903. [CrossRef] [PubMed]

68. Galvan, D.; Aquino, A.; Effting, L.; Mantovani, A.C.G.; Bona, E.; Conte-Junior, C.A. E-sensing and nanoscale-sensing devices associated with data processing algorithms applied to food quality control: A systematic review. Crit. Rev. Food Sci. Nutr. 2021, 1-41. [CrossRef]

69. Beckett, C.; Eriksson, L.; Johansson, E.; Wikström, C. Multivariate data analysis (MVDA). In Pharmaceutical Quality by Design; John Wiley \& Sons, Ltd.: Chichester, UK, 2018; pp. 201-225.

70. Horváth, G.; Ács, K. Essential oils in the treatment of respiratory tract diseases highlighting their role in bacterial infections and their anti-inflammatory action: A review. Flavour Fragr. J. 2015, 30, 331-341. [CrossRef]

71. Zhang, C.; Wu, Z.; Li, J.-W.; Zhao, H.; Wang, G.-Q. Cytokine release syndrome in severe COVID-19: Interleukin-6 receptor antagonist tocilizumab may be the key to reduce mortality. Int. J. Antimicrob. Agents 2020, 55, 105954. [CrossRef] [PubMed]

72. Li, Y.; Lai, Y.; Wang, Y.; Liu, N.; Zhang, F.; Xu, P. 1, 8-cineol protect against influenza-virus-induced pneumonia in mice. Inflammation 2016, 39, 1582-1593. [CrossRef]

73. Meeran, M.N.; Seenipandi, A.; Javed, H.; Sharma, C.; Hashiesh, H.M.; Goyal, S.N.; Jha, N.K.; Ojha, S. Can limonene be a possible candidate for evaluation as an agent or adjuvant against infection, immunity, and inflammation in COVID-19? Heliyon 2021, 7 , e05703. [CrossRef]

74. Benkaci-Ali, F.; Akloul, R.; Boukenouche, A.; De Pauw, E. Chemical composition of the essential oil of nigella sativa seeds extracted by microwave steam distillation. J. Essent. Oil Bear. Plants 2013, 16, 781-794. [CrossRef]

75. Ghanavi, Z.; Velayati, A.A.; Farnia, P.; Naji, A.M.; Kalatehjari, S. Essential oil composition of nigella sativa seeds from different populations of Iran. J. Essent. Oil Bear. Plants 2018, 21, 1652-1659. [CrossRef]

76. Yimer, E.M.; Tuem, K.B.; Karim, A.; Ur-Rehman, N.; Anwar, F. Nigella sativa L. (Black Cumin): A promising natural remedy for wide range of illnesses. Evid. Based Complement. Altern. Med. 2019, 2019, 1528635. [CrossRef] [PubMed]

77. Labib, M.; Sohrab, M. Protective effect of black seed oil from Nigella sativa against murine cytomegalovirus infection. Int. J. Immunopharmacol. 2000, 22, 729-740.

78. Games, E.; Guerreiro, M.; Santana, F.R.; Pinheiro, N.M.; De Oliveira, E.A.; Lopes, F.D.; Olivo, C.R.; Tibério, I.F.; Martins, M.A.; Lago, J.H.G.; et al. Structurally related monoterpenes p-cymene, carvacrol and thymol isolated from essential oil from leaves of lippia sidoides cham. (Verbenaceae) protect mice against elastase-induced emphysema. Molecules 2016, 21, 1390. [CrossRef] [PubMed]

79. Vimalanathan, S.; Hudson, J. Anti-infuenza virus activity of essential oils and vapors. Am. J. Essent. Oils Nat. Prod. 2014, 2, 47-53.

80. Kowalczyk, A.; Przychodna, M.; Sopata, S.; Bodalska, A.; Fecka, I. Thymol and thyme essential oil-new insights into selected therapeutic applications. Molecules 2020, 25, 4125. [CrossRef]

81. Gavanji, S.; Sayedipour, S.S.; Larki, B.; Bakhtari, A. Antiviral activity of some plant oils against herpes simplex virus type 1 in Vero cell culture. J. Acute Med. 2015, 5, 62-68. [CrossRef]

82. Elaissi, A.; Rouis, Z.; Ben Salem, N.A.; Mabrouk, S.; Ben Salem, Y.; Salah, K.B.H.; Aouni, M.; Farhat, F.; Chemli, R.; HarzallahSkhiri, F; et al. Chemical composition of 8 eucalyptus species' essential oils and the evaluation of their antibacterial, antifungal and antiviral activities. BMC Complement. Altern. Med. 2012, 12, 81. [CrossRef]

83. Astani, A.; Reichling, J.; Schnitzler, P. Screening for antiviral activities of isolated compounds from essential oils. Evid. Based Complement. Altern. Med. 2011, 2011, 253643. [CrossRef]

84. Pilau, M.R.; Alves, S.H.; Weiblen, R.; Arenhart, S.; Cueto, A.P.; Lovato, L.T. Antiviral activity of the Lippia graveolens (Mexican oregano) essential oil and its main compound carvacrol against human and animal viruses. Braz. J. Microbiol. 2011, 42, 1616-1624. [CrossRef]

85. Ralambondrainy, M.; Belarbi, E.; Viranaicken, W.; Baranauskienè, R.; Venskutonis, P.R.; Desprès, P.; Roques, P.; El Kalamouni, C.; Sélambarom, J. In vitro comparison of three common essential oils mosquito repellents as inhibitors of the Ross River virus. PLoS ONE 2018, 13, e0196757. [CrossRef] [PubMed]

86. Ursu, O.; Rayan, A.; Goldblum, A.; Oprea, T.I. Understanding drug-likeness. Wiley Interdiscip. Rev. Comput. Mol. Sci. 2011, 1, 760-781. [CrossRef]

87. Lipinski, C.A. Lead- and drug-like compounds: The rule-of-five revolution. Drug Discov. Today Technol. 2004, 1, 337-341. [CrossRef] [PubMed]

88. Abdallah, H.; Al-Abd, A.; El-Dine, R.S.; El-Halawany, A.M. P-glycoprotein inhibitors of natural origin as potential tumor chemo-sensitizers: A review. J. Adv. Res. 2015, 6, 45-62. [CrossRef] 
89. Glue, P.; Clement, R.P. Cytochrome P450 enzymes and drug metabolism-Basic concepts and methods of assessment. Cell. Mol. Neurobiol. 1999, 19, 309-323. [CrossRef] [PubMed]

90. Sepay, N.; Sekar, A.; Halder, U.C.; Alarifi, A.; Afzal, M. Anti-COVID-19 terpenoid from marine sources: A docking, admet and molecular dynamics study. J. Mol. Struct. 2021, 1228, 129433. [CrossRef]

91. Villoutreix, B.O.; Taboureau, O. Computational investigations of hERG channel blockers: New insights and current predictive models. Adv. Drug Deliv. Rev. 2015, 86, 72-82. [CrossRef]

92. Kamp, T.J.; Hamdan, M.H.; January, C.T. Chloroquine or hydroxychloroquine for COVID-19: Is cardiotoxicity a concern? J. Am. Hear. Assoc. 2020, 9, e016887. [CrossRef]

93. Chen, M.; Suzuki, A.; Borlak, J.; Andrade, R.J.; Lucena, M.I. Drug-induced liver injury: Interactions between drug properties and host factors. J. Hepatol. 2015, 63, 503-514. [CrossRef]

94. Adegbola, P.I.; Semire, B.; Fadahunsi, O.S.; Adegoke, A.E. Molecular docking and ADMET studies of Allium cepa, Azadirachta indica and Xylopia aethiopica isolates as potential anti-viral drugs for COVID-19. VirusDisease 2021, 32, 85-97. [CrossRef]

95. Letko, M.; Marzi, A.; Munster, V. Functional assessment of cell entry and receptor usage for SARS-CoV-2 and other lineage B betacoronaviruses. Nat. Microbiol. 2020, 5, 562-569. [CrossRef]

96. Anand, K.; Ziebuhr, J.; Wadhwani, P.; Mesters, J.R.; Hilgenfeld, R. Coronavirus main proteinase (3CL pro ) structure: Basis for design of anti-SARS drugs. Science 2003, 300, 1763-1767. [CrossRef]

97. Needle, D.; Lountos, G.T.; Waugh, D.S. Structures of the Middle East respiratory syndrome coronavirus3C-like protease reveal insights into substrate specificity. Acta Crystallogr. Sect. D Biol. Crystallogr. 2015, 71, 1102-1111. [CrossRef] [PubMed]

98. Ullrich, S.; Nitsche, C. The SARS-CoV-2 main protease as drug target. Bioorganic Med. Chem. Lett. 2020, 30, 127377. [CrossRef] [PubMed]

99. Hackbart, M.; Deng, X.; Baker, S.C. Coronavirus endoribonuclease targets viral polyuridine sequences to evade activating host sensors. Proc. Natl. Acad. Sci. USA 2020, 117, 8094-8103. [CrossRef]

100. Catella, C.; Camero, M.; Lucente, M.S.; Fracchiolla, G.; Sblano, S.; Tempesta, M.; Martella, V.; Buonavoglia, C.; Lanave, G. Virucidal and antiviral effects of Thymus vulgaris essential oil on feline coronavirus. Res. Veter Sci. 2021, 137, 44-47. [CrossRef]

101. de Oliveira, W.Q.; de Azeredo, H.M.C.; Neri-Numa, I.A.; Pastore, G.M. Food packaging wastes amid the COVID-19 pandemic: Trends and challenges. Trends Food Sci. Technol. 2021, 116, 1195-1199. [CrossRef] [PubMed]

102. Kumar, A.; Tandon, S.; Yadav, A. Chemical composition of the essential oil from fresh leaves of melaleuca Leucadendron L. from North India. J. Essent. Oil Bear. Plants 2005, 8, 19-22. [CrossRef]

103. Tisserand, R.; Young, R. Essential Oil Safety: A Guide for Health Care Professionals, 2nd ed.; Elsevier: Amsterdam, The Netherlands, 2014; ISBN 9780443062414.

104. Russo, E.B.; Marcu, J. Cannabis pharmacology: The usual suspects and a few promising leads. Adv. Pharmacol. 2017, 80, 67-134. [CrossRef] [PubMed]

105. Dasgupta, A. Antiinflammatory herbal supplements. In Translational Inflammation; Elsevier BV: Amsterdam, The Netherlands, 2019; pp. 69-91.

106. Habtemariam, S. The chemical and pharmacological basis of cloves (Syzygium aromaticum (L.) Merr. \& L.M.Perry) as potential therapy for type 2 diabetes and associated diseases. In Medicinal Foods as Potential Therapies for Type-2 Diabetes and Associated Diseases; Elsevier BV: Amsterdam, The Netherlands, 2019; pp. 551-578.

107. Da Costa, J.S.; Cruz, E.D.N.S.D.; Setzer, W.N.; Da Silva, J.K.D.R.; Maia, J.G.S.; Figueiredo, P.L.B. Essentials oils from brazilian eugenia and syzygium species and their biological activities. Biomolecules 2020, 10, 1155. [CrossRef] [PubMed]

108. Rana, V.S.; Verdeguer, M.; Blázquez, M.A. Chemical composition of the essential oil of zingiber zerumbet var. darcyi. Nat. Prod. Commun. 2012, 7, 1369-1370. [CrossRef]

109. Afzal, A.; Oriqat, G.; Khan, M.A.; Jose, J.; Afzal, M. Chemistry and biochemistry of terpenoids from curcuma and related species. J. Biol. Act. Prod. Nat. 2013, 3, 1-55. [CrossRef]

110. Akhtar, N.M.Y.; Jantan, I.; Arshad, L.; Haque, A. Standardized ethanol extract, essential oil and zerumbone of Zingiber zerumbet rhizome suppress phagocytic activity of human neutrophils. BMC Complement. Altern. Med. 2019, 19, 331. [CrossRef] [PubMed]

111. Maurya, S.; Marimuthu, P.; Singh, A.; Rao, G.P.; Singh, G. Antiviral activity of essential oils and acetone extracts of medicinal plants against papaya ring spot virus. J. Essent. Oil Bear. Plants 2005, 8, 233-238. [CrossRef]

112. Murakami, A.; Takahashi, M.; Jiwajinda, S.; Koshimizu, K.; Ohigashi, H. Identification of Zerumbone in Zingiber zerumbet Smith as a potent inhibitor of 12-O-Tetradecanoylphorbol-13-acetate-induced epstein-barr virus activation. Biosci. Biotechnol. Biochem. 1999, 63, 1811-1812. [CrossRef]

113. Loizzo, M.R.; Saab, A.; Tundis, R.; Statti, G.A.; Lampronti, I.; Menichini, F.; Gambari, R.; Cinatl, J.; Doerr, H.W. Phytochemical analysis and in vitro evaluation of the biological activity against herpes simplex virus type 1 (HSV-1) of Cedrus libani A. Rich. Phytomedicine 2008, 15, 79-83. [CrossRef]

114. Khumalo, G.; Sadgrove, N.; van Vuuren, S.; Van Wyk, B.-E. Antimicrobial activity of volatile and non-volatile isolated compounds and extracts from the bark and leaves of Warburgia salutaris (Canellaceae) against skin and respiratory pathogens. South Afr. J. Bot. 2019, 122, 547-550. [CrossRef]

115. Lim, T.K. Edible Medicinal and Non-Medicinal Plants, 1st ed.; Springer: Dordrecht, The Netherlands, 2012; ISBN 978-90-481-8660-0.

116. Belhassen, E.; Filippi, J.-J.; Brevard, H.; Joulain, D.; Baldovini, N. Volatile constituents of vetiver: A review. Flavour Fragr. J. 2015, 30, 26-82. [CrossRef] 
117. Lal, R.K.; Maurya, R.; Chanotiya, C.; Gupta, P.; Mishra, A.; Srivastava, S.; Yadav, A.; Sarkar, S.; Pant, Y.; Pandey, S.S.; et al. On carbon sequestration efficient clones/genotypes selection for high essential oil yield over environments in Khus (Chrysopogon zizanioides (L.) Roberty). Ind. Crop. Prod. 2020, 145, 112139. [CrossRef]

118. Thielmann, J.; Muranyi, P.; Kazman, P. Screening essential oils for their antimicrobial activities against the foodborne pathogenic bacteria Escherichia coli and Staphylococcus aureus. Heliyon 2019, 5, e01860. [CrossRef]

119. Burger, P.; Landreau, A.; Watson, M.; Janci, L.; Cassisa, V.; Kempf, M.; Azoulay, S.; Fernandez, X. Vetiver essential oil in cosmetics: What is new? Medicines 2017, 4, 41. [CrossRef]

120. Saiyudthong, S.; Pongmayteegul, S.; Marsden, C.A.; Phansuwan-Pujito, P. Anxiety-like behaviour and c-fosexpression in rats that inhaled vetiver essential oil. Nat. Prod. Res. 2015, 29, 2141-2144. [CrossRef]

121. Chou, S.-T.; Lai, C.-P.; Lin, C.-C.; Shih, Y. Study of the chemical composition, antioxidant activity and anti-inflammatory activity of essential oil from Vetiveria zizanioides. Food Chem. 2012, 134, 262-268. [CrossRef]

122. Sacan, A.; Ekins, S.; Kortagere, S. Applications and limitations of in silico models in drug discovery. Methods Mol. Biol. 2012, 910, 87-124. [CrossRef] 